\title{
KAJIAN PERBANDINGAN PRODUKTIVITAS DAN PENDAPATAN PERKEBUNAN POLA SISTEM INTEGRASI SAPI DAN KELAPA SAWIT (SISKA) DENGAN PERKEBUNAN TANPA POLA SISKA DI KABUPATEN SIAK
}

\author{
A COMPARATIVE STUDY ON THE PRODUCTIVITY LEVEL AND INCOME \\ BETWEEN THE PLANTATION WITH THE INTEGRATION OF CATTLE INTO \\ COCONUT PLANTATIONS FARMING SYSTEM AND WITHOUT THE \\ INTEGRATION OF CATTLE INTO COCONUT PLANTATIONS FARMING \\ SYSTEM IN SIAK REGENCY
}

\author{
Susy Edwina*, Jum'atri Yusri, Yusmini, Evi Maharani \\ Fakultas Pertanian Universitas Riau \\ *Corresponding email: susi_edwina@yahoo.com \\ (Diterima 10-11-2018; Disetujui 12-01-2019)
}

\begin{abstract}
ABSTRAK
Usaha perkebunan kelapa sawit telah memberikan kontribusi besar terhadap perekonomian masyarakat di Provinsi Riau. Seiring dengan perkembangan industri kelapa sawit, berbagai teknologi yang bertujuan untuk meningkatkan produksi dan pendapatan petani telah dikenalkan ke masyarakat. Salah satu dari teknologi tersebut adalah penerapan Sistem Integrasi Sapi dan Kelapa Sawit (SISKA). Program SISKA bertujuan untuk meningkatkan pendapatan petani kelapa sawit rakyat. Peningkatan pendapatan petani diharapkan seiring dengan tercapainya efisiensi usaha melalui pemanfaatan limbah kotoran ternak sebagai pupuk dan adanya sumber pendapatan baru dari hasil usaha ternak sapi. Penelitian ini bertujuan untuk mengkaji perbandingan produktivitas dan pendapatan kebun kelapa sawit pola SISKA dan non SISKA di Kabupaten Siak. Penelitian dilakukan dengan metode survei di dua lokasi yang mewakili, yaitu di Desa Sialang Palas Kecamatan Lubuk Dalam dan di Desa Teluk Merbau Kecamatan Dayun. Data penelitian adalah data primer yang diambil dengan teknik purposive sampling. Hasil penelitian menunjukkan produktivitas kebun pola SISKA yang menggunakan pupuk organik $18,899.93 \mathrm{~kg} / \mathrm{ha} / \mathrm{th}$, relatif lebih tinggi dari non SISKA yang tidak menggunakan pupuk organik 17,039.73/ha/th (signifikan pada $\alpha 15 \%$ ). Pendapatan kebun pola SISKA Rp 22.906.136,7/ha/th, relatif lebih tinggi dari non SISKA Rp 21.294.583,00/ha/th, namun perbedaannya tidak signifikan secara statistik, karena biaya produksi pola SISKA lebih tinggi.
\end{abstract}

Kata kunci :produktivitas, sistem integrasi sapi dan kelapa sawit, pendapatan

\begin{abstract}
Oil palm plantation is a sector that significantly contributes to the economy of the people in Riau Province. Along with the development of oil palm industry, various technologies that aim to increase production and income of oil palm farmers have been introduced to the society. One of these technologies is Sistem Integrasi Sapi dan Kelapa Sawit (SISKA). The aim of SISKA is to increase the income of smallholder oil palm farmers. Farmers' income is expected to increase with business efficiency through the use of waste from livestock as fertilizer in oil palm plantations and new sources of income are emerging as a result of livestock business. This study aims to examine the comparison of productivity and income of plantation using SISKA and without using SISKA in Siak Regency. The study was conducted using a survey method in two representative locations, namely Sialang Palas Village, Lubuk Dalam District and Teluk Merbau Village, Dayun District. The research data are the primary data gathered by purposive sampling technique. The results showed that the productivity of plantations with SISKA that use organic fertilizer 18,899.93
\end{abstract}


$\mathrm{kg} / \mathrm{ha} /$ year relatively higher than the productivity of plantations without SISKA that not use organic fertilizer 17,039.73/ha/year (significant at $\alpha 15 \%$ ). The income of oil palm plantations using SISKA $R p$ 22,906,136.7/ha/year relatively higher than the income of the plantations without SISKA Rp 21,294,583.00/ha/year, however the difference is not statistically significant, because using SISKA increase the production cost.

Keywords: productivity, cattle and oil palm integration system, income

\section{PENDAHULUAN}

Usaha perkebunan kelapa sawit telah memberikan kontribusi besar terhadap perekonomian masyarakat di Provinsi Riau. Oleh karena itu, perlu terus diupayakan berbagai kajian dalam rangka pengembangan teknologi untuk peningkatan produksi dan kesejahteraan pelaku ekonomi kelapa sawit.

Pola sistem integrasi sapi dan kelapa sawit (SISKA) adalah salah satu teknologi yang diintroduksikan kepada petani di Provinsi Riau sejak tahun 2007. Sistem integrasi sapi dan kelapa sawit adalah salah satu model dimana kegiatan usaha perkebunan kelapa sawit dan peternakan sapi dipadukan pada satu areal yang sama dengan adanya keterkaitan yang erat antara komponen tanaman dan ternak yang saling memanfaatkan limbah. Limbah berupa pelepah kelapa sawit dimanfaatkan sebagai input yaitu sumber pakan ternak, limbah ternak berupa kotoran baik cair maupun padat dimanfaatkan sebagai pupuk pada perkebunan.
Tujuan introduksi teknologi pola SISKA adalah untuk meningkatkan pendapatan petani kelapa sawit, seiring peningkatan efisiensi usaha melalui pemanfaatan limbah dan munculnya sumber pendapatan baru dari hasil pemeliharaan ternak sapi. Adopsi teknologi pola integrasi sapi dan kelapa sawit oleh petani diharapkan akan menyelesaikan permasalahan yang dihadapi petani kelapa sawit rakyat. Pendapatan petani kelapa sawit rakyat relatif masih rendah disebabkan beberapa hal yang saling berkaitan. Luas lahan perkebunan kelapa sawit rakyat relatif kecil dimana lebih dari 50\% luas lahan petani berada pada rentang 1-2 ha (Sari et al. 2015). Produktivitas masih di bawah produktivitas optimal yang diduga disebabkan oleh manajemen budidaya yang tidak mengikuti standar budidaya kelapa sawit untuk menghasilkan produksi yang optimal. Kondisi ini terutama terlihat pada pemupukan yang tidak sesuai dengan standar pemupukan. Menurut (Sarwani and Ananto 2010), Persepsi petani terhadap sifat-sifat 
teknologi pemupukan berimbang tidak selaras dengan tingkat adopsi.

Secara umum petani kelapa sawit rakyat memakai pupuk anorganik. Harga pupuk anorganik yang relatif mahal adalah salah satu penyebab pemupukan tidak sesuai dosis yang seharusnya. Biaya pemupukan dengan pupuk anorganik mencapai $25-30 \%$ dari total biaya produksi minyak sawit (Pahan Iyung 2010). Pola SISKA merekomendasikan pemakaian pupuk organik dari hasil limbah ternak sapi sehingga biaya produksi bisa lebih efisien.

Pemakaian pupuk organik pada perkebunan kelapa sawit perlu didukung dan harus terus digalakkan dalam rangka mewujudkan pertanian yang berkelanjutan. Pemberian pupuk anorganik secara terus menerus pada lahan pertanian akan berdampak pada menurunnya kesuburan tanah karena terjadinya kerusakan struktur tanah, penurunan $\mathrm{pH}$ tanah, mengganggu keseimbangan organisme di dalam tanah dan mengganggu kualitas air permukaan (Novizan 2001).

Informasi dari hasil kajian ilmiah tentang dampak pemberian pupuk organik terhadap produktivitas lahan perkebunan kelapa sawit sangat diperlukan sebagai bahan kajian pengembangan pola SISKA dan mewujudkan pertanian berkelanjutan.

Penerapan pertanian terpadu sistem integrasi sapi dan kelapa sawit membutuhkan dukungan sarana produksi yang relatif mahal bagi petani. Pemanfaatan limbah perkebunan sawit sebagai pakan ternak membutuhkan mesin pencacah (chopper) dan pengolahan limbah ternak sapi menjadi pupuk organik juga membutuhkan instalasi. Oleh karena itu, di awal program ini dikenalkan ke masyarakat, pemerintah memberikan berbagai bantuan fasilitas berupa pengadaan sarana produksi diantaranya mesin pengolahan limbah kelapa sawit, mesin pengolahan limbah ternak sapi dan pengadaan bibit sapi.

Setelah 10 tahun program ini berjalan, tidak semua kelompok tani yang mendapatkan bantuan SISKA menerapkan pola ini (Edwina, Susy, Evy Maharani 2015). Kondisi ini disebabkan oleh banyak faktor diantaranya adalah: (1) Penerapan pola SISKA membutuhkan curahan tenga kerja yang lebih besar karena adanya kegiatan budidaya ternak sapi dan kegiatan pengolahan limbah, dan (2) Kendala dalam mensosialisasikan pemakaian pupuk organik hasil limbah ternak sapi untuk perkebunan sawit. 
Petani khawatir substitusi sebagian pupuk anorganik dengan pupuk organik akan menurunkan produktivitas kebun.

Prinsip dasar kegiatan ekonomi adalah untuk mendapatkan manfaat yang optimal dari kegiatan tersebut. Bagi petani atau produsen, manfaat ekonomi adalah berupa pendapatan. Suatu teknologi akan mereka adopsi jika menurut mereka teknologi tersebut akan membuat pendapatan mereka lebih baik. Hal ini sesuai dengan pendapat (Rogers 1995), ada lima faktor yang menentukan dalam proses keputusan adopsi inovasi, yaitu: keuntungan relatif, keselarasan, kerumitan, dapat dicoba dan dapat dilihat hasilnya.

Pendapatan yang diterima petani merupakan selisih dari penerimaan dan total biaya yang dikeluarkan. Penerimaan bersumber dari jumlah produksi. Ada dua komponen yang mempengaruhi pendapatan, yaitu tingkat produksi dan biaya yang dikeluarkan. Penerimaan akan tinggi jika produktivitas yaitu produksi per unit input tinggi dan biaya bisa ditekan.

Konsep integrasi sapi dan kelapa sawit di sisi perkebunan kelapa sawit adalah efisiensi usaha dengan pemanfaatan pupuk organik sehingga biaya bisa diturunkan akibat dari penurunan jumlah pemakaian pupuk anorganik. Kombinasi pemakaian pupuk organik dan pupuk anorganik diharapkan tidak menurunkan produktivitas kelapa sawit.

Tujuan penelitian ini adalah menganalisis perbandingan produktivitas dan pendapatan antara perkebunan kelapa sawit pola SISKA dan non SISKA.

\section{METODE PENELITIAN}

Penelitian dilaksanakan di Kabupaten Siak Provinsi Riau. Tepatnya di dua kecamatan yang mewakili, yaitu Kecamatan Lubuk Dalam dan Kecamatan Dayun. Penentuan lokasi ditentukan secara sengaja dengan pertimbangan bahwa di daerah tersebut terdapat perkebunan kelapa sawit dengan pola SISKA.

Metode penelitian yang digunakan adalah metode survei. Populasi penelitian adalah petani kelapa sawit pola SISKA dan petani kelapa sawit yang tidak menerapkan (non SISKA). Pengambilan sampel dilakukan dengan metode purposive sampling. Sampel adalah petani yang memenuhi kriteria penelitian, yaitu telah menerapkan pola SISKA dengan mengaplikasikan pupuk organik hasil limbah ternak sapi pada perkebunan kelapa sawit minimal 2 tahun 
dan memiliki catatan produksi. Sampel petani kelapa sawit non SISKA dengan syarat umur tanaman kelapa sawit sama dengan umur kelapa sawit pola SISKA.

Data yang digunakan adalah data primer yang diperoleh melalui wawancara secara langsung dengan petani sampel menggunakan daftar pertanyaan (kuesioner). Data primer terdiri atas identitas petani (umur, lama pendidikan, pengalaman, jumlah anggota keluarga), jumlah faktor-faktor produksi yang digunakan (luas lahan, jumlah penggunaan pupuk, jumlah tenaga kerja, jumlah penggunaan herbisida), dan biayabiaya lain yang dikeluarkan selama produksi, serta jumlah produksi yang dihasilkan.

Analisis deskriptif digunakan untuk memaparkan keragaan perkebunan kelapa sawit pola SISKA. Analisis usahatani digunakan untuk menghitung pendapatan petani dengan menggunakan persamaan sebagai berikut (Soekartawi 1995):

$$
\mathrm{TR}=\mathrm{Q} \times \mathrm{P}
$$

dimana:

$$
\begin{aligned}
\mathrm{TR}= & \text { Total penerimaan }(\mathrm{Rp} / \mathrm{ha} / \text { tahun }) \\
\mathrm{Q}= & \text { Jumlah produksi yang dihasilkan } \\
& (\mathrm{Kg} / \mathrm{ha} / \mathrm{tahun}) \\
\mathrm{P}= & \text { Harga }(\mathrm{Rp} / \mathrm{kg})
\end{aligned}
$$

Pendapatan:

$$
\Pi=\mathrm{TR}-\mathrm{TC}
$$

dimana:

$$
\Pi=\text { Pendapatan }(\mathrm{Rp} / \mathrm{ha} / \text { tahun })
$$

$\mathrm{TR}=$ Penerimaan $(\mathrm{Rp} / \mathrm{ha} / \mathrm{tahun})$

$\mathrm{TC}=$ Total biaya tunai $(\mathrm{Rp} / \mathrm{ha} / \mathrm{tahun})$

$$
\mathrm{TC}=\mathrm{X}_{1} \cdot \mathrm{P}_{\mathrm{X} 1}+\mathrm{X}_{2} \cdot \mathrm{P}_{\mathrm{X} 2}+\ldots \mathrm{Xn} \cdot \mathrm{P}_{\mathrm{Xn}}
$$

Keterangan:

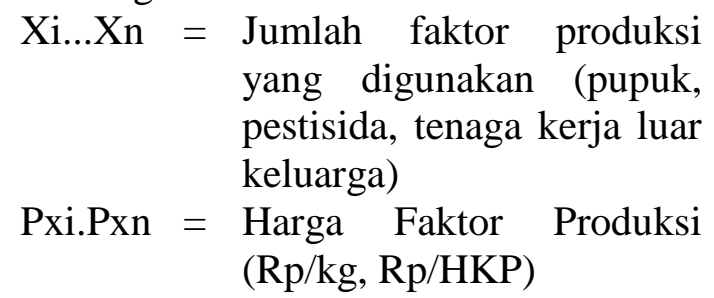

Analisis komparasi tingkat produktivitas dan pendapatan antara perkebunan kelapa sawit pola SISKA dengan non SISKA menggunakan uji statistik selisih rata-rata untuk sampel besar (Suharyadi 2009).

$$
\begin{gathered}
z=\frac{\left(\overline{x_{1}}-\overline{x_{2}}\right)(M 1-M 2)}{s x_{1}-x_{2}} \\
S_{x_{1}-x_{2}}=\sqrt{\frac{S_{1}^{2}}{n_{1}}+\frac{S_{2}{ }^{2}}{n_{2}}} \\
S_{1}^{2}=\frac{\sum\left(X_{1}-\overline{X_{1}}\right)^{2}}{n_{1}-1} \\
S_{2}^{2}=\frac{\sum\left(X_{2}-\overline{X_{2}}\right)^{2}}{n_{2}-1}
\end{gathered}
$$

Dimana:

$\overline{X_{1}}=$ Rata-rata produktivitas perkebunan pola SISKA

$\overline{X_{2}}=$ Rata-rata produktivitas perkebunan non SISKA

$\mathrm{n}_{1}=$ Jumlah sampel kelompok 1 (SISKA)

$\mathrm{n}_{2}=$ Jumlah sampel kelompok 2 (non SISKA)

$\mathrm{S}_{1}^{2}=$ Ragam produktivitas kelompok 1 (SISKA)

$\mathrm{S}_{2}{ }^{2}=$ Ragam produktivitas kelompok 2 (pola non SISKA) 
Hipotesis:

$$
\begin{aligned}
\text { Ho }= & \text { Produktivitas/pendapatan per- } \\
& \text { kebunan kelapa sawit pola } \\
& \text { SISKA sama dengan } \\
& \text { produktivitas/pendapatan per- } \\
& \text { kebunan kelapa sawit non } \\
& \text { SISKA } \\
\mathrm{Ha}= & \text { Produktivitas/pendapatan per- } \\
& \text { kebunan kelapa sawit pola } \\
& \text { SISKA tidak sama dengan } \\
& \text { produktivitas/pendapatan per- } \\
& \text { kebunan kelapa sawit non } \\
& \text { SISKA }
\end{aligned}
$$

Kaidah pengambilan keputusan (uji yang digunakan adalah pada taraf nyata $5 \%$ :

- Jika $Z_{\text {hit }}>Z_{\text {tabel}}$, maka $H_{0}$ ditolak dan $\mathrm{H}_{1}$ diterima

- Jika $\mathrm{Z}_{\text {hit }}<\mathrm{Z}_{\text {tabel }} \mathrm{H}_{0}$ diterima dan $\mathrm{H}_{1}$ ditolak

\section{HASIL DAN PEMBAHASAN}

\section{Keragaan Perkebunan Kelapa Sawit} Rakyat Pola SISKA di Kabupaten Siak

Faktor produksi pada perkebunan kelapa sawit adalah lahan, pupuk, herbisida dan tenaga kerja. Rata rata luas lahan petani 2 ha, tidak berbeda jauh dengan luas lahan pada penelitian Santoso (2017). Pupuk yang digunakan terdiri atas pupuk anorganik, yaitu urea, KCL, TSP dan NPK serta pupuk organik. Pupuk organik berasal dari limbah usaha ternak sapi berupa pupuk organik cair (urine) dan limbah padat (feses sapi). Terdapat perbedaan kondisi pemupukan antara petani kelapa sawit pola SISKA dengan non SISKA. Pada perkebunan kelapa sawit pola SISKA, disamping memberikan pupuk organik dari limbah ternak sapi, petani juga memberikan pupuk organik dari limbah tanaman kelapa sawit berupa tandan kosong kelapa sawit yang dikenal dengan nama tankos.

Jumlah pemberian pupuk organik pada perkebunan kelapa sawit pola SISKA di lokasi penelitian secara rinci disajikan pada Tabel 1 .

Tabel 1. Rata-rata Penggunaan Pupuk Organik pada Kebun Kelapa Sawit Pola SISKA Tahun 2018

\begin{tabular}{lc}
\hline \multicolumn{1}{c}{ Jenis Pupuk } & Jumlah (ha/Tahun) \\
\hline Feses $(\mathrm{kg})$ & $1.404,00$ \\
Urin (liter) & $1.040,50$ \\
Tankos $(\mathrm{kg})$ & $6.895,00$ \\
\hline
\end{tabular}

Petani kelapa sawit pola SISKA disamping memanfaatkan pupuk organik hasil limbah ternak sapi, mereka tetap memberikan pupuk anorganik/kimia, namun dengan jumlah yang jauh lebih sedikit dari jumlah pemberian pupuk kimia petani non SISKA. Menurut (Kurniadinata 2016), penggunaan pupuk anorganik dalam waktu yang lama dan berkelanjutan dapat mempengaruhi stuktur tanah menjadi kurang menguntungkan bagi tanaman kelapa sawit. Jumlah pemberian pupuk 
anorganik secara rinci disajikan pada Tabel 2.

Tabel 2. Rata-rata Penggunaan Pupuk Anorganik pada Pola SISKA dan Non SISKA

\begin{tabular}{lcc}
\hline \multirow{2}{*}{$\begin{array}{c}\text { Jenis } \\
\text { Pupuk }\end{array}$} & \multicolumn{2}{c}{ Jumlah Pemberian $(\mathbf{k g} / \mathbf{h a} / \mathbf{t h})$} \\
\cline { 2 - 3 } & Pola SISKA & Non SISKA \\
\hline Urea & 21,50 & 90,62 \\
TSP & 30,00 & 185,00 \\
KCL & 127,50 & 157,50 \\
NPK & - & 37,50 \\
ZA & - & 33,33 \\
Dolomit & 324,12 & 366,82 \\
Ponska & 90,62 & 128,20 \\
\hline Jumlah & 597,75 & 998,99 \\
\hline
\end{tabular}

Terdapat perbedaan antara petani kelapa sawit pola SISKA dengan petani non SISKA dalam hal pemberian pupuk anorganik, baik dari jenis pupuk yang diberikan maupun dalam jumlah/dosis pemberian. Konsekuensi dari manajemen perkebunan kelapa sawit pola SISKA berupa pemanfaatan pupuk organik hasil limbah usaha ternak sapi menurunkan jumlah pemakaian pupuk kimia/ anorganik dalam jumlah yang besar terutama untuk pupuk sumber $\mathrm{N}$, yaitu urea dan pupuk sumber P, yaitu TSP. Jumlah pemberian pupuk urea turun $76,27 \%$ dan jumlah pemberian pupuk TSP turun 83,6\%. Menurut (Marlina, Fahmi, and Satria 2018), terjadi peningkatan produktivitas dan pendapatan petani yang menggunakan pupuk gabungan karena mengurangi penggunaan pupuk kimia sebesar 50\% dan menghemat pengeluaran pupuk sebesar 19,14\%. Selanjutnya (Yeboah et al. 2009), menyatakan bahwa kombinasi pupuk anorganik dengan organik umumnya meningkatkan produksi karena bahan organik dapat memperbaiki kondisi tanah sehingga unsur hara lebih tersedia untuk tanaman.

Menurut (Kurniadinata 2016), Penggunaan pupuk kandang sapi sebagai pupuk organik mampu membantu mempertahankan struktur tanah, meningkatkan populasi jasad renik, mempertinggi daya serap dan daya simpan air serta menyediakan unsur hara yang diperlukan oleh tanaman kelapa sawit.

Tabel 3. Rata-rata Penggunaan Herbisida pada Pola SISKA dan Non SISKA

\begin{tabular}{lcc}
\hline \multirow{2}{*}{$\begin{array}{c}\text { Jenis } \\
\text { Pestisida }\end{array}$} & \multicolumn{2}{c}{$\begin{array}{c}\text { Jumlah Pemberian } \\
\text { (liter/ha/th) }\end{array}$} \\
\cline { 2 - 3 } & Pola SISKA & Non SISKA \\
\hline Gramaxone & 1,30 & 1,97 \\
Round Up & 1,18 & 1,46 \\
Benson & 0,41 & 0,35 \\
Topson & 0,63 & 0,21 \\
\hline \multicolumn{1}{c}{ Jumlah } & 3,52 & 3,99 \\
\hline
\end{tabular}

Jumlah pemakaian herbisida pada petani kelapa sawit pola SISKA tidak terlalu berbeda dengan jumlah pemakaian herbisida petani non SISKA. Sebagaimana jumlah pemakaian herbisida, jumlah pemakaian tenaga kerja juga tidak terlalu berbeda antara petani kelapa sawit pola SISKA dengan non SISKA. Satuan yang digunakan dalam 
pengukuran jumlah penggunaan tenaga kerja adalah hari kerja pria atau HKP. Satu HKP sama dengan satu hari kerja normal tenaga kerja laki laki dewasa. Data pada Tabel 4 menunjukkan bahwa pemakaian tenaga kerja luar keluarga lebih besar daripada pemakaian tenaga kerja dari dalam keluarga.

Hal ini menunjukkan bahwa petani kelapa sawit di lokasi penelitian lebih banyak menggunakan tenaga kerja upahan. Kondisi ini disebabkan karena kegiatan yang membutuhkan tenaga kerja paling besar pada budidaya kelapa sawit setelah masa produktif/tanaman menghasilkan adalah kegiatan pemanenan. Kegiatan pemanenan dilakukan 2 kali dalam satu bulan. Menurut (Mara and Fitri 2013), semakin besar penyerapan tenaga kerja maka semakin intensif pengelolaan kebun kelapa sawit.

Tabel 4. Rata-rata Penggunaan Tenaga Kerja pada Pola SISKA dan Non SISKA

\begin{tabular}{lcc}
\hline \multirow{2}{*}{ Tenaga Kerja } & \multicolumn{2}{c}{ Jumlah (HKP/ha/tahun) } \\
\cline { 2 - 3 } & Pola SISKA & Non SISKA \\
\hline Tenaga Kerja & 12,74 & 12,32 \\
Dalam Keluarga & & \\
\hline $\begin{array}{l}\text { Tenaga Kerja } \\
\text { Luar Keluarga }\end{array}$ & 27,50 & 27,06 \\
\hline \multicolumn{1}{c}{ Jumlah } & 40,24 & 39,38 \\
\hline
\end{tabular}

\section{Produktivitas}

Produktivitas adalah jumlah produksi suatu usahatani per hektar lahan. Produktivitas kelapa sawit petani bervariasi dengan rentang yang cukup besar, yaitu 23.683,50 kg. Tingkat produktivitas petani kelapa sawit pola SISKA di lokasi penelitian rata-rata 18.897,94 $\mathrm{kg} / \mathrm{ha} / \mathrm{th}$ dengan produksi terendah $5.790 \mathrm{~kg} / \mathrm{ha} / \mathrm{th}$ dan tertinggi $29.474,00 \mathrm{~kg} / \mathrm{ha} / \mathrm{th}$.

Produktivitas petani kelapa sawit pola SISKA relatif lebih tinggi daripada produktivitas petani kelapa sawit non SISKA. Produktivitas kebun sawit non SISKA juga sangat bervariasi diantara petani dimana rentangnya $19.496,50$ $\mathrm{kg} / \mathrm{ha} /$ tahun. Rata-rata produktivitas $17.039,74 \mathrm{~kg} / \mathrm{ha} / \mathrm{th}$ dengan nilai terendah $7.024 \mathrm{~kg} / \mathrm{ha} / \mathrm{th}$ dan tertinggi 26.520,50 $\mathrm{kg} / \mathrm{ha} / \mathrm{th}$

Banyak faktor yang menentukan tingkat produktivitas suatu lahan, baik dari faktor kondisi lahan dan manajemen budidaya, berupa jumlah pemberian faktor produksi serta bibit. Jika dianalisis secara deskriptif berdasarkan pelaksanaan dan data penelitian ini, diduga perbedaan produktivitas disebabkan karena dampak dari pemberian pupuk organik. Argumentasinya adalah bahwa kondisi awal dari perkebunan pola SISKA dan non SISKA adalah sama, baik dari jenis bibit, jumlah pemberian pupuk dan kondisi lahan. Perbedaan baru terjadi 
setelah pelaksanaan program SISKA berupa jenis pupuk yang digunakan.

\section{Pendapatan Perkebunan Kelapa Sawit Pola SISKA}

Pendapatan petani pola SISKA dan non SISKA dianalisis berdasarkan produksi dan faktor biaya yang dikeluarkan. Pendapatan adalah selisih antara penerimaan dari hasil penjualan output dengan total biaya yang dikeluarkan. Konsep pendapatan dalam penelitian ini adalah pendapatan yang benar-benar diterima petani atau pendapatan kerja keluarga. Pendapatan kerja keluarga adalah selisih antara jumlah penerimaan dengan biaya yang benar-benar dikeluarkan petani. Nilai faktor produksi milik sendiri seperti nilai tenaga kerja dalam keluarga tidak dihitung sebagai biaya.

Komponen yang menentukan pendapatan adalah penerimaan dari hasil penjualan produksi dan biaya-biaya yang dikeluarkan petani selama proses produksi. Penerimaan petani pola SISKA pada tahun 2017 rata-rata $\mathrm{Rp}$ 31.074.249,2/ha/tahun. Total penerimaan tersebut dihasilkan dari total penerimaan selama satu tahun (tahun 2017) berupa penjumlahan penerimaan petani selama 12 bulan.
Total biaya tunai yang dikeluarkan petani rata-rata $\mathrm{Rp} 8.168 .112,50 /$ ha/th. Biaya tunai yang dikeluarkan petani terdiri atas biaya untuk pembelian pupuk, pembelian pestisida dan herbisida serta biaya upah tenaga kerja. Komponen biaya terbesar adalah biaya untuk pemupukan yaitu sebesar $\mathrm{Rp}$ 4.951.937,50 yang memberikan kontribusi sebesar $60,83 \%$ terhadap total biaya tunai yang dikeluarkan petani.

Usaha perkebunan kelapa sawit pola SISKA dan non SISKA secara tradisional dikelola petani-peternak dan anggota keluarganya dan menjadi tumpuan untuk meningkatkan kesejahteraan mereka. Pengembangan usaha ternak sapi sebagai usaha keluarga dipengaruhi oleh berbagai faktor yang saling terkait, antara lain pendidikan, penggunaan input, pemasaran, kredit, kebijakan, perencanaan, penyuluhan, dan penelitian (Elly, Sinaga, and Kuntjoro 2008).

Tabel 5. Rata-rata Pendapatan Kebun Kelapa Sawit Pola SISKA

\begin{tabular}{clr}
\hline No & \multicolumn{1}{c}{ Uraian } & \multicolumn{1}{c}{$\begin{array}{c}\text { Rata-rata } \\
\text { (Rp/haTahun) }\end{array}$} \\
\hline 1 & Penerimaan & $31.074 .249,25$ \\
\hline 2 & Total biaya & $\mathbf{8 . 1 6 8 . 1 1 2 , 5 0}$ \\
& a. Pupuk Kimia & $2.194 .625,00$ \\
& b. Pupuk Organik & $2.757 .312,50$ \\
& c. Pestisida & $233.800,00$ \\
& d. Tenaga kerja & $2.982 .375,00$ \\
\hline 3 & Pendapatan & $\mathbf{2 2 . 9 0 6 . 1 3 6 , 7 5}$ \\
\hline
\end{tabular}


Total pendapatan yang diterima petani pada tahun 2017 adalah selisih dari penerimaan dengan total biaya yang dikeluarkan petani. Didapat pendapatan kerja (pendapatan yang benar benar diterima) petani kelapa sawit pola SISKA di lokasi penelitian rata-rata $\mathrm{Rp}$ 22.906.136,75/ha/tahun. Biaya pemupukan merupakan komponen biaya tertinggi. Menurut (Limbong 2011) dalam (Priyandari, Zakaria, and Syakura 2017), biaya pemupukan berkisar antara 40-60\% dari biaya pemeliharaan (pemupukan, penanggulangan hama dan penyakit, dan pemeliharaan tajuk).

\section{Analisis Perbandingan Produktivita antara Perkebunan Kelapa Sawit Pola SISKA dan perkebunan Sawit Non SISKA}

Hasil penelitian menunjukkan bahwa tingkat produktivitas perkebunan kelapa sawit pola SISKA relatif lebih tinggi daripada produktivitas non SISKA. Rata-rata produktivitas kebun kelapa sawit pola SISKA sebesar $18.897,94 \mathrm{~kg} / \mathrm{ha} / \mathrm{tahun}$, sedangkan non SISKA $17.039,74 \mathrm{~kg} / \mathrm{ha} / \mathrm{tahun}$. Jumlah produksi kebun kelapa sawit pola SISKA dan non SISKA secara rinci setiap bulan selama tahun 2017 disajikan pada Tabel 6.

Tabel 6. Produksi Kebun Kelapa Sawit Pola SISKA dan Non SISKA Tahun 2017

\begin{tabular}{clcc}
\hline \multirow{2}{*}{ No } & \multirow{2}{*}{ Bulan } & \multicolumn{2}{c}{ Produksi $(\mathbf{k g} / \mathbf{2}$ ha) } \\
\cline { 3 - 4 } & & Pola SISKA & Non SISKA \\
\hline 1 & Januari & $2.741,10$ & $2.300,65$ \\
2 & Februari & $2.725,95$ & $2.412,50$ \\
3 & Maret & $2.846,98$ & $2.351,48$ \\
4 & April & $3.214,55$ & $2.987,00$ \\
5 & Mei & $3.515,13$ & $3.101,60$ \\
6 & Juni & $3.697,60$ & $3.162,95$ \\
7 & Juli & $3.587,83$ & $3.821,33$ \\
8 & Agustus & $4.114,23$ & $3.686,55$ \\
9 & September & $3.594,60$ & $3.013,58$ \\
10 & Oktober & $2.923,40$ & $2.601,08$ \\
11 & November & $2.430,20$ & $2.357,98$ \\
12 & Desember & $2.404,33$ & $2.192,80$ \\
\hline
\end{tabular}

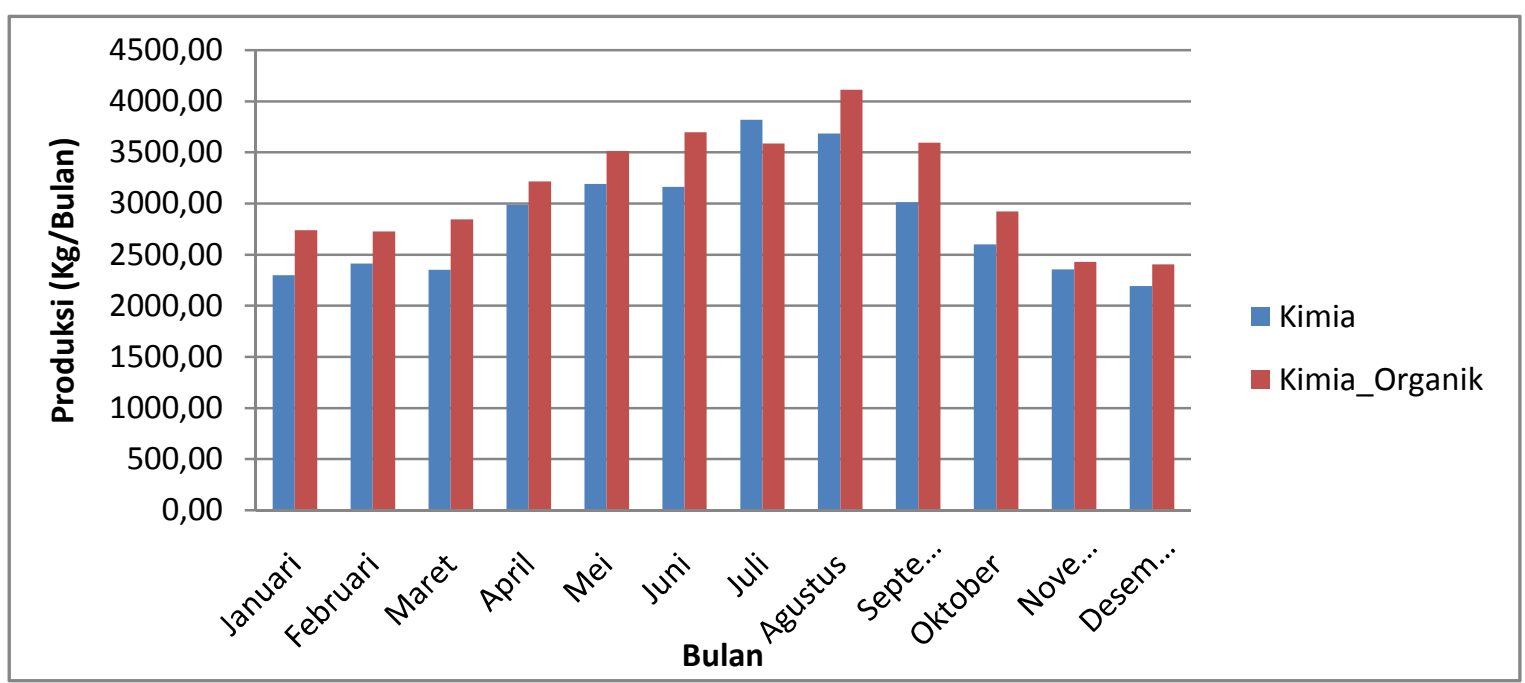

Gambar 1. Tingkat Produksi Kebun Kelapa Sawit Pola SISKA dan Non SISKA 
Produktivitas di antara petani bervariasi, baik pada kebun pola SISKA (menggunakan pupuk kimia dan organik) maupun non SISKA (pupuk kimia). Produktivitas kebun pola SISKA relatif lebih bervariasi dari pada non SISKA. Rentang produktivitas pada kebun pola SISKA $23.683,50 \mathrm{~kg}$ dengan simpangan baku $6.149,55 \mathrm{~kg}$; sedangkan pada kebun non SISKA $19.496,50 \mathrm{~kg}$ dengan simpangan baku 4.619,95 kg. Data ini menunjukkan bahwa produktivitas kebun kelapa sawit pola non SISKA relatif lebih seragam daripada kebun pola SISKA.

Data statistik deskriptif menunjukkan bahwa distribusi data produktivitas kelapa sawit, baik pada pola SISKA maupun non SISKA, di lokasi penelitian adalah terdistribusi secara simetris. Nilai Me dan rata-rata tidak terlalu berbeda jauh. Nilai Me dan rata-rata hitung untuk produktivitas kebun pola SISKA berturut turut 18.598,75 dan 18.897,93 dan Me serta rata-rata hitung data produktivitas kebun non SISKA berturut turut $16.921,00$ dan 18.517,27. Nilai modus kedua data juga terdapat di kelas interval yang terletak di tengah sebagaimana dapat dilihat pada Tabel 7.

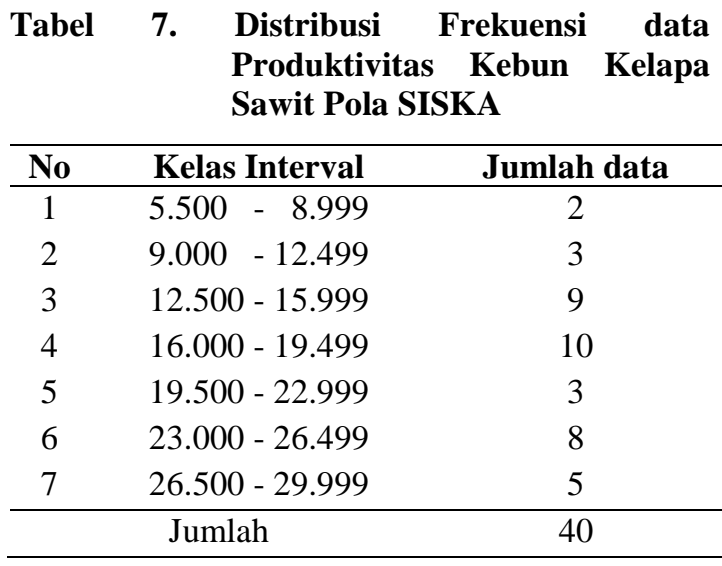

Tabel 8. Distribusi Frekuensi data Produktivitas Kebun Kelapa Sawit Non SISKA

\begin{tabular}{ccc}
\hline No & Kelas Interval & Jumlah data \\
\hline 1 & $7.000-9.799$ & 3 \\
2 & $9.800-12.599$ & 4 \\
3 & $12.600-15.399$ & 7 \\
4 & $15.400-18.199$ & 10 \\
5 & $18.200-20.999$ & 8 \\
6 & $21.000-23.799$ & 6 \\
7 & $23.800-26.599$ & 2 \\
\hline \multicolumn{2}{c}{ Jumlah } & 40 \\
\hline
\end{tabular}

Distribusi data yang simetris menginformasikan bahwa $68,25 \%$ dari petani, produktivitasnya berada di antara jarak 1 standar deviasi di sekitar rata-rata. Artinya sebagian besar data berada di sekitar rata-rata dan menunjukkan data relatif homogen (Hakim 2010).

Hasil uji selisih rata-rata menunjukkan bahwa produktivitas kebun kelapa sawit pola SISKA lebih tinggi dari pada produktivitas kebun kelapa sawit non SISKA (signifikan pada $\alpha 5 \%$ ). Hal ini menunjukkan bahwa pemberian pupuk organik dari limbah ternak sapi berupa pupuk organik dari urine dan 
pupuk kompos dari kotoran padat ternak sapi berdampak positif terhadap produktivitas kebun kelapa sawit.

Hasil penelitian (A. M. Bamualim, F. Madarisa, Y. Pendra 2015) juga menunjukkan hal serupa dimana pemberian pupuk kombinasi antara pupuk kimia dan pupuk organik pada perkebunan kelapa sawit berdampak terhadap peningkatan produksi sawit sebesar 39-48\%. Hasil penelitian ini menunjukkan selisih antara produktivitas kebun pola SISKA dengan kebun non SISKA hanya sebesar 10,90\%. Rendahnya perbedaan produktivitas ini diduga karena data pada penelitian ini adalah data produksi kelapa sawit pada umur 27 tahun. Umur 27 tahun sudah termasuk fase tidak produktif lagi pada kelapa sawit.

\section{Analisis Perbandingan Pendapatan}

Pendapatan kebun kelapa sawit pola SISKA rata-rata $\mathrm{Rp}$ 22.906.136,75/ha/tahun, relatif lebih tinggi daripada non SISKA Rp 21.294.583,00/ha/tahun. Penyebab pendapatan petani kelapa sawit pola SISKA relatif lebih tinggi adalah karena produktivitas kebun pola SISKA lebih tinggi daripada non SISKA sehingga penerimaan petani kebun pola SISKA lebih tinggi.

Biaya produksi kebun kelapa sawit pola SISKA relatif lebih tinggi dari pada kebun kelapa sawit non SISKA. Namun perbedaanya tidak terlalu jauh sehingga pendapatan yang diterima petani pada kebun kelapa sawit pola SISKA tetap lebih tinggi.

Tabel 9. Rata-rata Pendapatan Kebun Kelapa Sawit Pola SISKA dan Non SISKA (Rp/ha/tahun)

\begin{tabular}{|c|c|c|c|}
\hline No & Uraian & Pola SISKA & Non SISKA \\
\hline 1 & Penerimaan & 31.074.249,2 & 29.059.705,90 \\
\hline \multirow[t]{4}{*}{2} & Pupuk Kimia & 2.194 .625 & $4.634 .260,00$ \\
\hline & Pupuk Organik & 2.757 .312 & 0 \\
\hline & Pestisida & 233.800 & $275.095,00$ \\
\hline & Tenaga Kerja & 2.982 .375 & $2.855 .767,86$ \\
\hline 3. & Total biaya & 8.168.112 & $7.765 .122,86$ \\
\hline 4 & Pendapatan & $22.906 .136,75$ & $21.294 .583,00$ \\
\hline
\end{tabular}

Hasil uji statistik selisih rata-rata menunjukkan bahwa perbedaan pendapatan antara kebun kelapa sawit pola SISKA dan kebun non SISKA tidak signifikan secara statistik. Hasil penelitian ini sesuai dengan penelitian 
(Santoso 2017), namun demikian berbeda dengan hasil penelitian (Sirait, Lubis, and Sinaga 2015) yang menunjukkan adanya perbedaan sangat siginifikan tingkat pendapatan antara petani yang berintegrasi dan tanpa integrasi, karena petani yang menerapkan sistem integrasi akan memperoleh penerimaan yang berasal dari 2 (dua) usaha, yaitu usahatani kelapa sawit ditambah penerimaan yang berasal dari usaha ternak sapi.

\section{KESIMPULAN}

1. Rata-rata produktivitas kelapa sawit petani pola SISKA rata-rata $18.899,94 \mathrm{~kg} / \mathrm{ha} / \mathrm{th}, \quad$ dengan pendapatan rata-rata $\mathrm{Rp}$ 22.906.137,75/ha/th. Di samping pupuk organik, petani kelapa sawit pola SISKA juga memberikan pupuk kimia namun jumlahnya lebih sedikit dari jumlah yang diberikan petani non SISKA.

2. Produktivitas perkebunan kelapa sawit pola SISKA relatif lebih tinggi daripada produktivitas perkebunan kelapa sawit tanpa pola SISKA (signifikan pada $\alpha$ 5\%), dan pendapatan perkebunan kelapa sawit pola SISKA relatif lebih tinggi daripada pola non SISKA, namun perbedaannya tidak signifikan secara statistik.

\section{DAFTAR PUSTAKA}

A. M. Bamualim, F. Madarisa, Y. Pendra, E. Mawardi dan Asmak. 2015. Kajian Inovasi Integrasi Tanaman Ternak Melalui Pemanfaatan Hasil Ikutan Tanaman Sawit Untuk Meningkatkan Produksi Sapi Lokal Sumatera Barat. Jurnal Peternakan Indonesia 17(2): 83-93.

Edwina, Susy, Evy Maharani, Bungaran Situmorang. 2015. Karakteristik Petani Sistem Integrasi Kelapa Sawit yang Mempengaruhi Adopsi Inovasi di Kabupaten Pelalawan. Prosiding Seminar Nasional, edited by Siti Rusimah, 515-24. Yogyakarta: Universitas Muhammadiyah Yogyakarta. http://agribisnis.umy.ac.id.

Elly, Femi Hadidjah, Bonar M Sinaga, and Sri Utami Kuntjoro. 2008. Pengembangan Usaha Ternak Sapi Rakyat Melalui Integrasi SapiTanaman di Sulawesi Utara. Jurnal Litbang Pertanian 27(2007): 63-68.

Hakim, Abdul. 2010. Statistik Deskriptif Untuk Ekonomi \& Bisnis. Yogyakarta: Ekonisia Yogyakarta. https://doi.org/http://dx.doi.org/10. 1016/j.ehj.2004.06.013.

Kurniadinata, Odit. 2016. Pemanfaatan Feses dan Urin Sapi Sebagai Pupuk Organik dalam Perkebunan Kelapa Sawit (Elaeis Guineensis Jacg.). In Seminar Optimalisasi Hasil Samping Perkebunan Kelapa Sawit dan Industri Olahannya Sebagai Pakan Ternak, 65-72.

Limbong, K Rano. 2011. Manajemen Pemupukan Tanaman Kelapa Sawit (Elaeis Guineensis Jaqc .) di Gunung Sari Estate, PT. Ladangrumpun Suburabadi, 
Minamas Plantation, Kabupaten Bumbu, Kalimantan Selatan. Tesis. Institut Pertanian Bogor. Bogor.

Mara, Armen, and Yanuar Fitri. 2013. Dampak Perkebunan Kelapa Sawit Rakyat Terhadap Pendapatan Wilayah Desa (PDRB) di Provinsi Jambi. Agrisep 13(1): 101-10.

Marlina, Yeni, Idqan Fahmi, and Arif Satria. 2018. Customer Discovery Of Biofertilizer Business (A Lesson From PT PHN Experience). Manajemen \& Agribisnis 15: 10717.

Novizan, Ir. 2001. Petunjuk Pemupukan yang Efektif. Depok: AgroMedia Pustaka.

Pahan Iyung. 2010. Panduan Lengkap Kelapa Sawit. Jakarta: Penebar Swadaya.

Priyandari, Yusuf, Roni Zakaria, and Abdan Syakura. 2017. Sistem Pakar Pemupukan Kelapa Sawit Menggunakan Metode Forward Chaining. Performa 16(2): 98-106.

Rogers, Everett M. 1995. Diffusion of Innovations, 4th Edition. 5th ed. New York.

Santoso, Agung Budi. 2017. Analisis Pendapatan Terhadap Karakteristik Usahatani Integrasi Tanaman Perkebunan-Sapi: Kasus di Desa Mesa, Kabupaten Maluku Tengah. Jurnal Ilmu Pertanian Indonesia 22(2): 108-14. https://doi.org/10.18343/jipi.22.2.1 08.

Sari, Vira Irma, Sudradjat, Sugiyanta, and Sudradjat. 2015. Peran Pupuk Organik dalam Meningkatkan Efektivitas Pupuk NPK pada Bibit Kelapa Sawit di Pembibitan Utama. Jurnal Agronomi Indonesia (Indonesian Journal of Agronomy) 43(2): 153. https://doi.org/10.24831/jai.v43i2.1 0422.
Sarwani, Muhrizal, and E Eko Ananto. 2010. Persepsi dan Adopsi Petani Terhadap Teknologi Pemupukan Berimbang pada Tanaman Padi dengan Indeks Pertanaman 300. Penelitian Pertanian Tanaman Pangan 29(1984): 157-65. https://doi.org/10.1128/CVI.0520511.

Sirait, P, Z Lubis, and M Sinaga. 2015. Analisis Sistem Integrasi Sapi dan Kelapa Sawit dalam Meningkatkan Pendapatan Petani di Kabupaten Labuhanbatu. Jurnal Agrica 8(2): $1-20$.

http://ojs.uma.ac.id/index.php/agric a/article/view/126.

Soekartawi. 1995. Analisis Usahatani. Jakarta: UI Press. https://doi.org/10.1182/blood-200707-099648.

Suharyadi, Purwanto. 2009. Statistika Untuk Ekonomi dan Keuangan Modern. Jakarta: Salemba Empat.

Yeboah, E, P Ofori, G W Quansah, E Dugan, and S P Sohi. 2009. Improving Soil Productivity through Biochar Amendments to Soils. African Journal of Environmental Science and Technology 3(2): 34-41. 